\title{
CHANGES IN ANAEROBIC POWER OF YOUTH SOCCER PLAYERS IN AN ANNUAL TRAINING CYCLE
}

\section{Petar Peev, Marin Gadev, Borislava Petrova}

Abstract

Introduction: It is a well-known fact that short high intensity actions are decisive for football game. The energy for these actions is ensured from anaerobic energy system. The lack of information about this subject defines the aim of our research which was set as research of changes of indicators which characterize anaerobic power of youth football players. Methodology: It includes the following methods of research: anthropometry, chronometry, test of exercise bike and statistical analysis. Results: The data from Wingate test are proof for increasing of the average values of the most informative signs of this test. We found out statistical improvement of the values of the signs such as Peak power $(P P)$, Average power $(A P)$ and Minimal power $(M P)$. Their values increase from 539.96 to 721.54 watts for PP; from 410.58 to 514.07 watts for AP and from 277.23 to 339.15 watts for MM. The same improvement of 1.66 seconds we can see from the data of the field test " $3 \times 50 \mathrm{~m}$ shuttle". Discussion and conclusions: As a whole this research found out improvement of the informative signs from laboratory and field tests in the annual training cycle. Statistical nonsignificant improvement was found only in the indicator MM from second to third test. This fact leads us to the conclusion that this indicator is not good enough to detect changes in a short period of time. We also found improvement of the PP and AP respectively with 33.63 and $25.20 \%$. Our study is in unison with the conception that the period of 13-14 years is suitable for development of the speed and speed endurance abilities.

Key words: anaerobic power, anaerobic characteristics, dynamics, annual training cycle, youth soccer players

\section{Introduction:}

It is well-known fact that high intensity action are crucial for football game (Бъчваров et al., 2005, Nikolaidis, 2011, Stølen et al., 2005, Reilly \& Williams, 2003). The energy for these actions is supplied from anaerobic energy system. Throughout human development the abilities for these actions are being increased and their peak is through puberty. Despite these facts we don't know the rates of their increments also there is lack of information about changes in the annual training cycle. Accumulation of knowledge about these processes could help us to optimize the training process.

The lack of information about this problem defines the aim of this research. It comes down to research of changes in anaerobic indicators that characterize anaerobic power of 13-14 years old soccer players.

The implications of this goal are the research tasks that are:

1. First task is to define changes of indicators that characterize anaerobic power which are derived from laboratory and field tests;

2. Second task is to define level of significance of cumulative values of these indicators throughout the three testing periods in annual training cycle.

\section{Methods:}

It includes the following methods of research: anthropometry, chronometry, exercise bike test (30-seconds Wingate test), statistical processing of the results (descriptive statistics and repeated descriptive statistics with Student's t distribution). The research was proceeded in three stages with length of one football season. The testing procedures were done: in the end of the first preparation period (first half of the season); in the end of the second preparation period (second part of the season) and in the end of the competitive period (the end of the football season).

Results:

The data from changes of "Wingate" test, testify for the increasing of the most informative indicators of anaerobic power throughout of the annual training cycle. They can be seen at Table 1 (Пеев, 2017). We found statistical significance of increasing of the values of the indicators "peak power" (PP) in the range of 539,96 to 721,54 watts and "average power" (AP) - from 410,58 to 514,07 watts. The last indicator, that is "minimal power" (MP) is being increased with the smallest one range (277,23 to 339,15 watts). In addition of the data of the changes of the anaerobic characteristics from laboratory test we did the field test " $3 \times 50 \mathrm{~m}$ shuttle run" that characterizes level of development of the speed endurance of 13-14 years old football players. (Пеев, 2017). We found out improvement of the average time for running the test from 26,56 to 24,90 seconds (Table 2). 
Table 1

Variability of the changes in the anaerobic characteristics in an annual training cycle

\begin{tabular}{|c|c|c|c|c|c|c|c|c|c|}
\hline Indicator & PP & AP & MP & PP 2 & AP 2 & MP 2 & PP 3 & AP 3 & MP 3 \\
\hline $\mathbf{X}$ & 539,96 & 410,58 & 277,23 & 643,21 & 488,68 & 334,40 & 721,54 & 514,07 & 339,15 \\
\hline $\mathbf{m 0}$ & 20,87 & 12,54 & 7,65 & 15,83 & 13,10 & 14,41 & 16,83 & 14,95 & 15,00 \\
\hline $\mathbf{S}$ & 80,84 & 48,59 & 29,65 & 61,30 & 50,73 & 55,82 & 65,19 & 57,90 & 58,10 \\
\hline $\mathbf{M e}$ & 550,08 & 421,02 & 277,11 & 639,81 & 490,36 & 339,98 & 704,68 & 517,57 & 360,40 \\
\hline $\mathbf{A s}$ & $-0,716$ & $-0,532$ & $-0,022$ & $-1,076$ & 0,009 & 0,282 & 0,228 & $-0,237$ & $-0,773$ \\
\hline $\mathbf{E x}$ & $-1,107$ & $-1,452$ & $-1,283$ & 1,136 & 0,083 & 0,063 & $-1,078$ & $-1,534$ & $-1,238$ \\
\hline $\mathbf{R}$ & 206,18 & 126,35 & 82,95 & 207,88 & 173,34 & 181,29 & 193,66 & 148,37 & 143,38 \\
\hline $\mathbf{X m a x}$ & 410,69 & 339,97 & 234,55 & 514,99 & 403,05 & 255,12 & 629,67 & 439,61 & 247,83 \\
\hline $\mathbf{X m i n}$ & 616,87 & 466,32 & 317,50 & 722,87 & 576,39 & 436,41 & 823,33 & 587,98 & 392,21 \\
\hline $\mathbf{V \%}$ & 14,97 & 11,83 & 10,69 & 9,53 & 10,38 & 16,69 & 9,03 & 11,26 & 17,13 \\
\hline
\end{tabular}

Table 2

Variability of the indicator time for running the test "Shuttle running $3 \times 50 \mathrm{~m}$

\begin{tabular}{|c|c|c|c|}
\hline Indicator $\boldsymbol{~}$ & $\mathbf{t} \mathbf{3 \times \mathbf { 5 0 }} \mathbf{~}$ & $\mathbf{t} \mathbf{3 \times 5 0} \mathbf{~} \mathbf{2}$ & $\mathbf{t} \mathbf{3 \times 5 0} \mathbf{~} \mathbf{3}$ \\
\hline $\mathbf{X}$ & 26,13 & 24,95 & 24,67 \\
\hline $\mathbf{m 0}$ & 0,31 & 0,30 & 0,30 \\
\hline $\mathbf{S}$ & 1,12 & 1,09 & 1,08 \\
\hline $\mathbf{M e}$ & 26,30 & 24,80 & 24,30 \\
\hline $\mathbf{A s}$ & $-0,007$ & 0,201 & 0,309 \\
\hline $\mathbf{E x}$ & $-0,532$ & $-0,835$ & $-0,990$ \\
\hline $\mathbf{R}$ & 3,70 & 3,50 & 3,30 \\
\hline $\mathbf{X m a x}$ & 24,30 & 23,30 & 23,20 \\
\hline $\mathbf{X m i n}$ & 28,00 & 26,80 & 26,50 \\
\hline $\mathbf{V \%}$ & 4,29 & 4,36 & 4,38 \\
\hline
\end{tabular}

The data of the indicators that were received from Wingate test show that there is steady increasing of the anaerobic abilities of the youth soccer players. In the same time the coefficient of variations (CV\%) vary in the limits of 9,03 to $17,13 \%$, which defines the sample as homogeneous for some of the indices and relatively homogenous for others. The test of normality shows that the skewness and kurtosis are smaller than 1 so we can conclude that the variables have normal distribution. These two conclusions allow us to do a repeated descriptive statistics of the data. Exception of this made just the indicator MP which coefficient of variation $(16,69$ and 17,13$)$ and skewness and kurtosis (bigger than 1) don't allow us to do a descriptive statistic.

The same conclusions are applicable for the shuttle run test, where the CV\% is around $4,5 \%$ and in the same time skewness and kurtosis are under 1.

\section{Discussion:}

We found from the research that PP is increased in the two researched periods. The difference between them is that the increase is bigger in the first period than in the second one (table 3 ).

Table 3

Significance of the increase of the indicator PP for the researched period

\begin{tabular}{|c|c|c|c|c|c|c|c|c|}
\hline \multirow{2}{*}{ Indicator $\rrbracket$} & \multicolumn{4}{|c|}{ 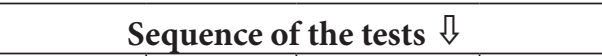 } & \multirow{2}{*}{ d } & \multirow{2}{*}{ d $\%$} & \multirow{2}{*}{ temp } & \multirow{2}{*}{$\mathbf{P}(\mathbf{t})$} \\
\hline & $x_{1}$ & $\mathbf{s}_{1}$ & $\mathbf{x}_{2}$ & $s_{2}$ & & & & \\
\hline \multirow[t]{2}{*}{$\mathrm{PP}(1-2)$} & 539,96 & 80,84 & 643,21 & 61,30 & 103,25 & 19,12 & 6,50 & 100,00 \\
\hline & $x_{2}$ & $\mathrm{~s}_{2}$ & $x_{3}$ & $\mathrm{~s}_{3}$ & & & & \\
\hline \multirow[t]{2}{*}{$\mathrm{PP}(2-3)$} & 643,21 & 61,30 & 721,54 & 65,19 & 78,33 & 12,18 & 8,32 & 100,00 \\
\hline & $x_{1}$ & $s_{1}$ & $x_{3}$ & $\mathrm{~s}_{3}$ & & & & \\
\hline $\mathrm{PP}(1-3)$ & 539,96 & 80,84 & 721,54 & 65,19 & 181,58 & 31,30 & 10,76 & 100,00 \\
\hline
\end{tabular}

The increase of results for the researched period is This is due to the fact that inherently the indicator $31,30 \%$. The similar increment is observed in other PP is indicator that discloses the development of the cases (Swilowski et al, 2006, Пеев et al., 2016) with anaerobic alactic energy system which potential is similar research methods and one of the reasons is increased in the process of growth (Inbar et al., 1996). the increased muscle mass (Gareth Jr. et al.. 1996). 
The second indicator that we researched (Average Power) characterizes anaerobic lactic energy system (Inbar et al., 1996). Again we observe significant increase of the results in the two researched periods (respectively 19,02\% and 5,20\%) (table 4). The bigger increase in the first researched period is due to implicated methodology for speed endurance development (Пеев, 2017). In support of this statement are the researches of Swilowski et al. (2013) and Dragijsky et al. (2017) who point out that the trainings influence the results of these kind of researches.

Table 4

Significance of the increase of the indicator AP for the researched period

\begin{tabular}{|c|c|c|c|c|c|c|c|c|}
\hline \multirow{2}{*}{ Indicator $\sqrt{|c|}$ Sequence of the tests $\sqrt{*} \mathbf{d}$} & \multirow{2}{*}{$\mathbf{d} \%$} & \multirow{2}{*}{$\mathbf{t}_{\text {emp }}$} & \multirow{2}{*}{$\mathbf{P}(\mathbf{t})$} \\
\cline { 2 - 9 } & $\mathbf{x}_{1}$ & $\mathbf{s}_{1}$ & $\mathbf{x}_{2}$ & $\mathbf{s}_{2}$ & & & 10,29 & 100,00 \\
\hline $\mathbf{A P}_{(1-2)}$ & 410,58 & 48,59 & 488,68 & 50,73 & 78,10 & 19,02 & 10,29 \\
\hline & $\mathbf{x}_{2}$ & $\mathbf{s}_{2}$ & $\mathbf{x}_{3}$ & $\mathbf{s}_{3}$ & & & & \\
\hline $\mathbf{A P}_{(2-3)}$ & 488,68 & 50,73 & 514,07 & 57,90 & 25,39 & 5,20 & 3,72 & 99,77 \\
\hline & $\mathbf{x}_{1}$ & $\mathbf{s}_{1}$ & $\mathbf{x}_{3}$ & $\mathbf{s}_{3}$ & & & & \\
\hline $\mathbf{A P}_{(1-3)}$ & 410,58 & 48,59 & 514,07 & 57,90 & 103,49 & 24,22 & 21,15 & 100,00 \\
\hline
\end{tabular}

Laboratory test data show increase in all of the test " $3 \times 50 \mathrm{~m}$ shuttle run" (Table 5), that serves us researched indicators and as we mentioned earlier to define the level of development of the speed this increase is bigger in the first researched period. endurance ability (Гъдев, 2013 и Peev et al., 2017).

This tendency is also maintained in the case of field

Table 5

Significance of the increase of the indicator time for " $3 \times 50 \mathrm{~m}$ shuttle run" for the researched period

\begin{tabular}{|c|c|c|c|c|c|c|c|c|}
\hline \multirow{2}{*}{ Indicator $\sqrt{ }$} & \multicolumn{4}{|c|}{ Sequence of the tests $\rrbracket$} & \multirow{2}{*}{ d } & \multirow{2}{*}{$\mathrm{d} \%$} & \multirow{2}{*}{$t_{\text {emp }}$} & \multirow{2}{*}{$\mathbf{P}(\mathbf{t})$} \\
\hline & $x_{1}$ & $s_{1}$ & $x_{2}$ & $\mathbf{s}_{2}$ & & & & \\
\hline \multirow{2}{*}{$t$ for $3 \times 50 M_{(1-2)}$} & 26,56 & 1,93 & 25,32 & 1,75 & 1,24 & 4,67 & 7,58 & 100,00 \\
\hline & $x_{2}$ & $s_{2}$ & $x_{3}$ & $s_{3}$ & & & & \\
\hline \multirow{2}{*}{$t$ for $3 \times 50 M_{(2-3)}$} & 25,32 & 1,75 & 24,90 & 1,35 & 0,42 & 1,66 & 3,53 & 99,57 \\
\hline & $x_{1}$ & $s_{1}$ & $x_{3}$ & $\mathbf{s}_{3}$ & & & & \\
\hline$t$ for $3 \times 50 M$ & 26,56 & 1,93 & 24,90 & 1,35 & 1,66 & 6,25 & 8,51 & 100,00 \\
\hline
\end{tabular}

The improve in time for running the distance of laboratory and field tests. Laboratory indicator the test are accordingly 4,67\% $(\mathrm{P}(\mathrm{t})=100,00 \%)$ and $\mathrm{PP}$ and AP are increased accordingly with $33,63 \%$ $1,66 \%(\mathrm{P}(\mathrm{t})=99,57 \%)$. This makes an increment and $25,20 \%$ but the time for " $3 \times 50 \mathrm{~m}$ shuttle run" in total of $6,25 \%(\mathrm{P}(\mathrm{t})=100,00 \%)$ that shows the is increased just with $6,25 \%$. Of course these cumulative effect of implicated training influences discrepancies were expected for two reasons: first for development of the speed endurance ability.

In general our research found an increase of the most informative indicators of laboratory and fields test in the annual training cycle. We found that most of the indicators have significant increase throughout the researched period. Exception of this makes only the indicator MP. This fact suggests that this indicator is not reliable source of information for shorter periods of time. We found some discrepancies for the values of the increase of the indicators from of all it is consequence of the complexity of the different abilities that are needed for the running test and second reason is that the youngsters can't convert their current abilities at a maximum level.

\section{Conclusions:}

Our study is in unison with the conception of the authors Шишков et al. (1985), Антипов et al. (2008), Лапшин (2010), Гъдев (2013) that the period of 13-14 years is suitable for development of the speed and speed endurance abilities. 


\section{Acknowledgments:}

We express our gratitude to Borislav Kiosev, head coach of Youth academy of PFC "Levski" Sofia for his help and cooperation.

\section{Literature:}

Dragijsky, M, T. Maly, F. Zahalka, E. Kunzmann, M. Hank (2017), Seasonal Variation of Agility, Speed and EndurancePerformance in Young Elite Soccer Players, Sports, 5(1), 12

Gareth Jr., W. E., D. T. Kirkendall, S. R. Contiguglia (1996), The U.S.Soccer Sports medicine book, Baltimore, Williams and Wilkins, p. 504

Inbar.,O. Bar-Or, J. Skinner (1996), The wingate anaerobic test, Human kinetics, pp. 110

Śliwowski, R., M. Laurentowska, E. Michalak, A. Wieczorek, J. Wieczorek (2006), Changes in anaerobic performance in young football players in an annual training cycle, Studies in physical culture and tourism, 13

Śliwowski, R., M. Andrzejewski, A. Wieczorek, A. Barinow-Wojewódzki, Ł. Jadczak, S. Adrian, M. Pietrzak, S. Wieczorek (2013), Changes in the anaerobic threshold in an annual cycle of sport training of young soccer players, Biology of Sport, Jun; 30(2): 137-143

Антипов А., В. Губа, С. Тюленков (2008), Диагностика и тренировка двигательных способностей в детскоюношеском футбол, Москва, Советский спорт, с. 152 Гъдев М. (2013), Теоретични основи и методикотехнологични аспекти на неспецифична кондиционна подготовка в детско-юношеския футбол, С., Докторат, с. 311

Лапшин, О. Б. (2010), Теория и методика подготвки юньіх футболистов, Человек, Москва, с. 174

Пеев, П. (2017), Изследване на методически подходи за въздействие върху развитието на скоростната издръжливост при 13-14 годишни футболисти, докторат, София, с.149

Пеев, П., Г. Иванова, С. Цветков, Борислава Петрова, Инна Иванова (2016), Вариативност на абсолютните стойностина Wingate test при 13-14-годишни футболисти, Лека атлетика и наука, 1(16): 70-74

Шишков А., Л. Димитров, М. Мадански, В. Генчев (1985), Обучение и подготовка на млади футболисти, София, Виф, с. 107

Бъчваров, М., Л. Димитров, А. Гигов (2005) Футбол: Преса, кондиция, натиск, София, НСА - Прес, с. 120 Nikolaidis, P. (2011) Anaerobic power across adolescence in soccer players, Human movement; 12(4): 342347

Stølen, T., K. Chamari, C. Castagna, U. Wisløff (2005), Physiology of soccer: An update, Sports Medicine, 35(6): 501-36

Reilly, T., M. Williams (2003), Science and soccer Second edition, Routhledge, London, p. 326.

Peev, P. S. Tsvetkov, M.Gadev (2017) Reliability of field test "3x50 m Shuttle" to determine anaerobic power for football players aged 13-14, Research in kinesiology, 1(45): 105-108

\section{Petar Peev, PhD}

National Sport Academy "Vassil Levski"

Department: Track and field

Sofia, Studentski grad, 1700

GSM: +359878354911

pe60dj@abv.bg 